\title{
Kandungan Gizi dan Aktivitas Antioksidan Permen Jelly Buah Pedada (Sonneratia Caseolaris) dengan Penambahan Karagenan
}

\author{
Dini Wulan Dari ${ }^{1}$, Dwi Tria Ramadani ${ }^{2}$, Aisah $^{3}$ \\ ${ }^{1,2,3}$ Program Studi S1 Ilmu Gizi , Sekolah Tinggi Ilmu Kesehatan Baiturrahim Jambi \\ Email:wulandaridini62@gmail.com
}

Submitted : 05/10/2019

Accepted: 05/01/2020

Published: 07/09/2020

\begin{abstract}
Pedada fruit (Sonneratia caseolaris) is one of the mangrove varieties that has a high nutritional content and has the potential as an antioxidant. In general, pedada is still underutilized by the community because it tastes sour and feels tight when consumed directly. One of the efforts in utilizing the pedada fruit is processing it into jelly candy. The purpose of this study was to determine the chemical characteristics of pedada jelly candy with the addition of carrageenan. This research is an experimental design using a quantitative descriptive approach with $P 2 K 2(100 \mathrm{ml}$ of pedada fruit juice and $20 \mathrm{gr}$ carrageenan) and POK2 contol samples (without pedada fruit juice and $20 \mathrm{gr}$ of carrageenan). To find out the chemical characteristics were tested Carbohydrate, protein, fat, fiber, water content, ash content, vitamin $C$ and Antioxidant activity. This research was conducted in MayAugust 2018. Jelly candy making was carried out at the STIKes Baiturrahim Jambi Nutrition and Food Laboratory, Chemical characteristics were tested by proximate analysis (Carbohydrate, protein, fat, fiber, water content, ash content), iodimetry (vitamin c) method and DPPH (Antioxidant activity) method.The best treatment in making Pedada jelly candywhich is very preferred, namely P2K2 (100 ml pedada fruit juice and $20 \mathrm{gr}$ carrageenan) with a carbohydrates (69.83\%), protein (5.66\%), fat (9.89\%), water content (39.26\%), ash content (9.67\%), fiber $(0.67 \%)$, vitamin $C(14.08 \%)$ and antioxidant activity (67.34\%).
\end{abstract}

Keywords: carrageenan, chemical characteristics, jelly candy, pedada fruit

\begin{abstract}
Abstrak
Buah pedada merupakan salah satu varietas mangrove yang memiliki kandungan gizi yang tinggi dan berpotensi sebagai antioksidan. Secara umum buah pedada masih kurang dimanfaatkan oleh masyarakat karena rasanya yang asam dan terasa sepat jika dikonsumsi langsung. Salah satu upaya dalam pemanfaatan buah pedada tersebut yaitu mengolahnya menjadi permen jelly. Penelitian ini bertujuan ini untuk mengetahui karakteristik kimia permen jelly buah pedada dengan penambahan karagenan. Penelitian ini merupakan desain eksperimen menggunakan pendekatan deskriptif kuantitatif dengan sampel P2K2 (100 ml sari buah pedada dan 20 gram karagenan) dan sampel kontrol P0K2 (tanpa sari buah pedada dan 20 gram karagenan) untuk mengetahui karakteristik kimia diuji dengan analisis proksimat (Karbohidrat, protein, lemak, serat, kadar air, kadar abu), metode iodimetri (vitamin c) dan metode DPPH (Aktivitas Antioksidan). Penelitian ini telah dilaksanakan pada bulan MeiAgustus 2018, pembuatan permen jelly dilakukan di Laboratorium Gizi dan Pangan STIKes Baiturrahim Jambi, analisis karakteristik kimia dilakukan di Laboratorium MIPA STIKes Baiturrahim Jambi, Laborium Fakultas Peternakan dan Laboratorium Terpadu Universitas Jambi. Karakteristik kimia permen jelly buah pedada dengan perlakuan terbaik yang sangat disukai yaitu P2K2 (100 ml sari buah pedada dan 20 gr karagenan) dengan nilai berupa karbohidrat $(69,83 \%)$, protein $(5,66 \%)$, lemak $(9,89 \%)$, kadar air $(39,26 \%)$, kadar abu $(9,67 \%)$, serat $(0,67 \%)$, vitamin C $(14,08 \%)$ dan aktivitas antioksidan $(67,34 \%)$.
\end{abstract}

Kata kunci : buah pedada, karagenan, karakteristik kimia, permen jelly 


\section{PENDAHULUAN}

Salah satu negara yang memiliki hutan mangroveserta memiliki kekayaan hayatinya adalah Indonesia, dengan luas antara 2,5 hingga 4,5 juta hektar merupakan mangrove yang terluas didunia (Kusmana, 2008). Kabupaten Tanjung Jabung Barat yang berada di Pantai Timur Provinsi Jambi dikenal sebagai kawasan hutan mangrove yang menjadi salah satu wilayah untuk melestarikan pantai. Hutan mangrove mempunyai banyak varietas yang dapat dimanfaatkan oleh masyarakat sekitar untuk meningkatkan perekonomian salah satunya buah pedada dengan spesies Sonneratia caseolaris(Sari, 2013).

Buah pedada merupakan buah yang bagian dasarnya terbungkus kelopak bunga, berbentuk bola, dan ujung buahnya bertangkai. Buah pedada tidak beracun dan langsung dapat dimakan buah pedada memilki rasa yang asam dan aroma yang khas. Buah pedada banyak ditemui di daerah perairan payau yang merupakan tempat bertumbuhnya tanaman mangrove (Susanto et al., 2008). Buah pedada (Sonneratia caseolaris) dapat dimanfaatkan sebagai sumber pangan (Septiadi, 2010). Daging buah pedada memiliki kandungan gizi yang tinggi. Kandungan gizi per 100 gbuah pedada segar terdapat karbohidrat $77,5 \%$, protein $9,21 \%$, lemak 4,81\%, vitamin A 11,21 (RE), vitamin $B_{1} 5,04 \mathrm{mg}$, vitamin $B_{2} 7,65 \mathrm{mg}$ dan vitamin $C 56,74 \mathrm{mg}$ (Manalu, 2011) serta memiliki kadar air 67,8\% dan kadar abu 1,17\% (Ramadani et al, 2019).Buah pedada merupakan salah satu tumbuhan yang berpotensisebagai antioksidan, tumbuhan ini mengandung senyawa alkaloid, flavonoid, glikosida,saponin dan fenol (Avenido dan Serrano, 2012).

Secara umum buah pedada masih kurang dimanfaatkan oleh masyarakat karena rasanya yang asam dan terasa sepat jika dikonsumsi langsung. Kandungan kadar airnya yang tinggi hingga $79 \%$ menyebabkan buah pedada mudah membusuk (Febrianti, 2010). Buah pedada memiliki kandungan gizi dan antioksidan yang belum dimanfaatkan dan buah tersebut biasanya hanya dibiarkan berjatuhan begitu saja sehingga berserakan dan tidak termanfaatkan dengan baik oleh masyarakat sekitarnya, sehingga perlu dilakukan pengolahan agar buah pedada dapat dimanfaatkan dengan baik dan dapat dijadikan sebagai sumber pangan. Salah satu upaya dalam pemanfaatan buah pedada tersebut yaitu mengolahnya menjadi permen jelly (Afriyanto et al., 2016).

Permen jelly merupakan permen yang terbuat dari campuran sari buahbuahan,bahan pembentuk gel atau dengan penambahan komponen flavoring untukmenghasilkan berbagai macam rasa dengan bentuk fisik jernih dan transparan(Atmaka et al., 2013).

Bahan utama dalam pembuatan permen jellymenurut SNI No. 3547.2.2008 tahun 2008 adalah gula, penambahan komponen hidrokoloidseperti agar, gum, pektin, pati, karagenan,gelatin dan lain-lain yang digunakan untuk modifikasi tekstur sehinggamenghasilkan produk yang kenyal.

Dalam penelitian ini, bahan tambahan yang digunakan adalah karagenan. Karagenan merupakan salah satu gelling agent yang dapat digunakan pada pembuatan permen jelly. Karagenan merupakan getah rumput laut yang diperoleh dari hasil ekstraksi rumput laut merah dengan menggunakan air atau larutan alkali pada suhu yang tinggi (Muchlisah, 2012). Karagenan memiliki kandungan serat, kaya akan komponen seperti karbohidrat, protein, lemak, enzim, asam nukleat, asam amino, mineral, dan vitamin A, B, C, D, E, dan $\mathrm{K}$ (Karyani, 2013)dan memiliki kandungan unsur-unsur mineral makro yaitu kalsium sebesar 186,00 ppm dan fosfor sebesar 2,76 ppm serta unsur mineral mikro yaitu besi sebesar 2,12 ppm 
(Winarno, 2008).Karagenan mempunyai sifat fungsional yang sangat baik dan berguna untuk mengontrol kadar air dan berfungsi sebagai sistem yang menstabilkan dalam pangan, memperbaiki tekstur dan sistem fungsional(Langendorff et al., 2000).

Maka berdasarkan uraian diatas, perlu dilakukan pengolahan untuk meningkatkan pemanfaatan buah pedada(Sonneratia caseolaris) dan mendapatkan bahan pangan bergizi yang murah dan mudah didapat serta menjadi inovasi olahan produk yang baru maka peneliti tertarik untuk memanfaatkan buah pedada sebagai bahan baku pembuatan permen jelly, dengan tujuan untuk mengetahui pengaruh penambahan karagenan terhadap karakteristik kimia pada produk permen jelly pedada. Berdasarkan perlakuan terbaik pada penelitian pendahuluan Ramadani et al (2019) permen jelly buah pedada dengan penambahan karagenan, maka dalam penelitian ini, perlakuan yang digunakan yaitu perlakuan terbaik P2K2 (konsentrasi sari buah $100 \mathrm{ml}$ dan 20 gr karagenan) dan perlakuan kontrol P0K2 (tanpa sari buah dan 20 gr karagenan). Sehingga diharapkan hasil penelitian ini dapat menjadi referensi dalam menghasilkan produk permen jelly buah pedada dengan karakteristik kimia terbaik.

\section{METODE PENELITIAN}

Penelitian ini merupakan desain eksperimen dengan menggunakan pendekatan deskriptif kuantitatif dengan sampel P2K2 dan sampel kontrol P0K2. Sampel ini merupakan perlakuan terbaik berdasarkan penelitian pendahuluan Ramadani et al (2019) pada permen jelly buah pedada. Kemudian dilakukan analisis karakteristik kimia (karbohidrat, protein, lemak, serat, kadar air, kadar abu, vitamin C, aktivitas antioksidan). Adapun kombinasi perlakuan antara penambahan sari buah pedada dan karagenan adalah sebagai berikut :
1. $\mathrm{P} 0 \mathrm{~K} 2=$ Kontrol $($ tanpa sari buah pedada) dengan karagenan 20 gr

2. $\mathrm{P} 2 \mathrm{~K} 2$ = Sari buah pedada $100 \mathrm{ml}$ dengan karagenan 20 gr

\section{Pelaksanaan Penelitian Waktu dan Tempat Penelitian}

Penelitan dilaksanakan pada bulan MeiAgustus 2019. Tempat pembuatan permen jellydilaksanakan di Laboratorium Gizi dan Pangan Stikes Baiturrahim Jambi. tempat analisis karakteristik kimia (Karbohidrat, lemak, protein, kadar air, kadar abu, serat) dilakukan di Laboratorium Peternakan Fakultas Peternakan Universitas Jambi, analisis vitamin $\mathrm{C}$ dilakukan di Laboratorium MIPA STIKes Baiturrahim Jambi dan analisis aktivitas antioksidan dilakukan di Laboratorium Terpadu Universitas Jambi.

\section{Bahan dan Alat Penelitian}

Alat yang digunakan untuk pembuatan permen jelly buah pedada yaitu panci, spatula, baskom, blender, timbangan, kain saring, loyang, gelas ukur, oven. Alat yang digunakan untuk analisis yaitu cawan porselen, desikator, oven, penjepit, neraca analitik, tanur, pembakar bunzen, labu destruksi dan destilasi, distilator, pemanas lstrik labu elemeyer $250 \mathrm{ml}$, biuret, corong, pipet, gelas ukur, batu didih, soxhlet, kertas saring, eksikator, pinset, pompa vakum, mortar corong bucher, gelas piala, cawan porselen, pompa vakum, aluminium foil, tabung reaksi ultrasonic water bath, pipet volum dan sentrifuse, homogenizer spektrofotometer uv-vis.

Bahan yang digunakan untuk pembuatan permen jelly yaitu buah pedada (Sonneratia caseolaris) yang diperoleh dari Kabupaten Tanjung Jabung Barat Kecamatan Manunggul, sukrosa, sirup fruktosa $55 \%$, asam sitrat, karagenan, air. Bahan yang digunakan untuk analisis yaitu $\mathrm{H} 2 \mathrm{SO} 4$ pekat, $\mathrm{H} 2 \mathrm{SO} 40,3 \mathrm{~N}, \mathrm{NAOH} 40 \%$, NAOH 0,3 N dan $1,5 \mathrm{~N}$, katalis campuran, aquades, HCL 
p.a., $\mathrm{K} 2 \mathrm{Cr} 2 \mathrm{O} 70,01 \mathrm{~N}, \mathrm{Na} 2 \mathrm{~S} 2 \mathrm{O} 30,01 \mathrm{~N}$, $\mathrm{H} 2 \mathrm{SO} 4$ 4N, Amilum, KI, alfatekoferol, methanol,dan 1.1-diphenyl-2-picrylhydrazyl (DPPH)

\section{Prosedur Pembuatan}

\section{Pembuatan Sari Buah Pedada}

Proses pembuatan sari buah pedada mengacu pada Afriyanto et al (2016). Pembuatan diawali dengan penghancuran buah pedada. Pedada dipilih dengan kriteria masih segar dan tidak busuk. Buah pedada dibersihkan dengan air yang mengalir, kemudian dikupas lalu buah pedada dipotong-potong dan dihancurkan dengan menggunakan blender sambil ditambahkan air sebanyak 1:1. Hancuran buah pedada kemudian disaring menggunakan kain agar biji tidak tercampur untuk diambil sari buah pedada.

\section{Pembuatan Permen Jelly}

Proses pembuatan permen jelly mengacu pada Nursyamsiati (2013) dan Isnanda et al (2016). Sirup fruktosa dan sukrosa dipanaskan sampai larut. Kemudian masukan karagenan sesuai rasio perlakuan dilarutkan dengan sari buah pedada. Kemudian dipanaskan hingga mencapai suhu $80-100^{\circ} \mathrm{C}$ (selama 10 menit) sambil diaduk sampai mengental, kemudian suhu diturunkan dan ditambahkan asam sitrat sambil diaduk lalu dituangkan ke dalam loyang atau cetakan. Adonan didalam loyang didiamkan selama 10 jam dalam suhu ruang lalu dipotong. Kemudian dikeringkan dalam oven selama 3 jam pada suhu $50-70^{\circ} \mathrm{C}$ selama 3 jam.

\section{Metode Analisis}

Analisis Protein (Metode Kjeldhal, AOAC 1984)

Timbang 0,3 gr sampel (I), masukkan kedalam labu destruksi, tambahkan katalis campuran 0,2 gr dan $\mathrm{H} 2 \mathrm{SO} 4$ pekat $5 \mathrm{ml}$,
Panaskan campuran tersebut dalam lemari asam. Larutan kemudian dimasukan kedalam labu destilasi dan diencerkan dengan dengan $60 \mathrm{ml}$ akuades. Masukkan beberapa buah batu didih. Siapkan labu erlemeyer yang telah berisi $25 \mathrm{ml} \mathrm{H} 2 \mathrm{SO} 40,3 \mathrm{~N}$ dan 2 tetes indicator campuran (methyl red $0,1 \%$ dan bromcresol green $0,2 \%$ dalam alcohol) dan hubungkan kesistem destilasi. Tuang perlahan-lahan $20 \mathrm{ml} \mathrm{NaOH} \mathrm{40 \%} \mathrm{dan} \mathrm{segera}$ hubungkan dengan destilator. Penyulingan dilakukan dengan hingga nitrogen dari cairan tersebut tertangkap oleh H2SO4. Labu Erlenmeyer berisi sulingan diambil dan dititer kembali dengan $\mathrm{NaOh} 0,3 \mathrm{~N}(\mathbf{J})$ hingga perubahan warna menjadi hijau. Bandingkan dengan titer blangko (K).

\section{Analisis Lemak (Metode Soxhlet, AOAC 1984)}

Timbang sampel sebanyak 1 gr (L) dan bungkus dengan kertas saring bebas lemak, lalu dikeringkan dalam oven $105^{\circ} \mathrm{C}$ selama 5 jam. Dinginkan sampel dalam eksikator dan timbang (M). sampel dimasukkan kedalam tabung ekstraksi soxhlet. Ala soxhlet diisi dengan pelarut melalui kondensor dengan alat corong. Alat pendingin dialirkan dan pemanas dihidupkan. Lakukan ekstraksi selama 16 jam sampai pelarut pada alat soxhlet terlihat jernih. Sampel dikeluarkan dari alat soxhlet dan dikeringkan dalam oven $105^{\circ} \mathrm{C}$ selama $5 \mathrm{jam}$, kemudian didinginkan dalam eksikator dan timbang $(\mathbf{N})$.

\section{Analisis Karbohidrat (AOAC, 1995)}

Pengukuran

karbohidrat menggunakan metode by difference.

\section{Analisis Kadar Serat (AOAC, 1984)}

Keringkan kertas saring whatman no. 41 didalam oven $105^{\circ} \mathrm{C}$ selama satu jam dan timbang (O). Timbang Dengan teliti $1 \mathrm{~g}(\mathbf{P})$ sampel dan masukkan kedalam gelas piala. Tambahkan $50 \mathrm{ml} \quad \mathrm{H} 2 \mathrm{SO} 4 \quad 0,3 \quad \mathrm{~N}$ dan 
didihkan selama 30 menit.setelah 30 menit, tambhakan dengan cepat $50 \mathrm{ml} \mathrm{NaOH} \mathrm{1,5} \mathrm{N}$ dan didihkan selama 30 menit. Kemudian cairan disaring melalui kertas saring yang telah diketahui beratnya didalam corong Buchner yang telah dihubungkan dengan pompa vakum. Kertas saring bersama residu dicuci berturut-turut dengan $50 \mathrm{ml} \mathrm{H} 2 \mathrm{O}$ panas, $50 \mathrm{ml} \mathrm{H} 2 \mathrm{SO} 40,3 \mathrm{~N}, 50 \mathrm{ml} \mathrm{H} 20$ panas dan aceton. Lalu kertas saring berisi residu dimasukkan kedalam cawan porselen bersih dan kering oven cawan berisi sampel dikeringkan dalam oven $105^{\circ} \mathrm{C}$ sampai didapat berat yang konstan, didinginkan dalam eksikator dan ditimbang (Q).

\section{Analisis Kadar Air (Metode Oven, AOAC 1984)}

Cawan porselen yang telah dicuci bersih, dikeringkan didalam oven selama \pm 1 jam pada suhu $105^{\circ} \mathrm{C}$. Cawan kemudian didinginkan didalam eksikator sekitar 10-20 menit kemudian ditimbang (C). Sampel ditimbang sebanyak 0,5-1 gr (D) dan dimasukkan kedalam cawan porselen. Kemudian cawan dan sampel tersebut dikeringkan dalam oven $105^{\circ} \mathrm{C}$ selama \pm 12 16 jam. Cawan dan sampel ( E ) dikeluarkan dari oven dan didinginkan dalam eksikator selama 10-20 menit sampai diperoleh berat tetap.

\section{Analisis Kadar Abu (Metode Oven, AOAC 1984)}

Cawan porselin yang telah dicuci bersih, dikeringkan didalam oven selama 1 jam pada suhu $105^{\circ} \mathrm{C}$. Cawan kemudian didinginkan didalam eksikator sekitar 10-20 menit kemudian ditimbang (F). Sampel ditimbang sebanyak 3 gr untuk hijauan atau 5 gr untk konsentrat (G) dan dimasukkan kedalam cawan porselen. Pijarkan sampel yang terdapat dalam cawan porselin di atas pembakar Bunsen hingga tak berasap. Selanjutnya bakar cawan porselin berisi sampel dalam tanur bersuhu $600^{\circ} \mathrm{C}$. Biarkan sampel terbakar selama 4-5 jam atau sampai warna sampel berubah menjadi putih. Mainkan tombol tanur kemudian tinggu hingga suhu cawan dalam tanur mencapai $102^{\circ} \mathrm{C}$ sebelum dipindahkan dalam eksikator. Setelah dingin cawan ditimbang dengan teliti (H).

\section{Analisis Vitamin C Metode Iodimetri (SNI 01-2891-1992)}

Timbang sampel sebanyak 200 gram , kemudian dihancurkan sampai dihasilkan bubur lalu sampel yang dihancurkan, ditimbang lagi sebanyak 20 gram. Kemudian dilarutkan dengan aquades pada labu $100 \mathrm{ml}$ sampai tanda batas. Larutan tersebut disaring dan filtratnya dipipet sebanyak $25 \mathrm{ml}$. Pertama lakukan standarisasi Na2S2O3 0,1 N dengan $\mathrm{K} 2 \mathrm{Cr} 207 \quad 0,1 \quad \mathrm{~N}$, dilanjutkan standarisasi I2 0,01 N dengan Na2S2O3.

\section{Analisis Aktivitas Antioksidan Metode DPPH}

Ekstraksi Sampel untuk Analisa Aktivitas Antioksidan (Baba et al, 2016 yang telah dimodifikasi), sampel permen jelly yang telah dihaluskan sebanyak 1 gram dilarutkan terlebih dulu kedalam pelarut (metanol dan air), kemudian dihomogenizer selama 1 jam. Selanjutnya di sentrigugasi dengan kecepatan 3.500 rpm selama 10 menit. Supernatan yang diperoleh dianalisa aktivitas antioksidannya dan Analisa Aktivitas Antioksidan (Selviet al., 2003) yaitu terhadap masing-masing ekstrak dilakukan uji aktivitas antioksidan dengan menggunakan metode penangkapan radikal DPPH (Selvi, et al., 2003) . Dibuat serangkaian larutan sampel dari keempat bahan yang diekstrak pekat dengan variasi konsentrasi 100 ppm, 200 ppm, 300 ppm,400 ppm, dan 500 ppm, menggunakan pelarut DMSO. Untuk penentuan aktivitas antioksidan, sebanyak 0,2 ml larutan sampel dipipet dengan pipet mikro kedalam vial, 
kemudian ditambahkan 3,8 ml larutan DPPH $50 \mu \mathrm{M}$. Campuran larutan dihomogenkan dan dibiarkan selama 30menit ditempat gelap. Serapan diukurdengan spektrofotometer $U V$ $V i s$ pada panjang gelombang $517 \mathrm{~nm}$. Untuk control positif digunakan $\alpha$-tokoferol, perlakuan yang sama seperti sampel. \% inhibisi.

\section{HASIL DAN PEMBAHASAN}

Karakteristik kimia suatu produk makanan merupkan faktor yang sangat rentan terhadap perubahan perlakuan sebelum, selama, dan sesudah proses pengolahan. Tetapi dengan adanya proses pengolahan dapat meningkatkan aroma dan cita rasa suatu produk makanan (Nasrulloh, 2015). Berikut hasil uji karakteristik kimia permen jelly buah pedada dapat dilihat pada Tabel 2 .

Tabel 2 Hasil Uji Karakteristik Kimia Permen Jelly Buah Pedada

\begin{tabular}{lcc}
\hline \multirow{2}{*}{ Zat Gizi (\%) } & \multicolumn{2}{c}{ Hasil Analisis } \\
\cline { 2 - 3 } & P0K2 & P2K2 \\
\hline KH & $49,62 \pm 0,17$ & $69,83 \pm 0,59$ \\
Protein & $2,94 \pm 0,64$ & $5,66 \pm 0,69$ \\
Lemak & $1,84 \pm 0,08$ & $9,89 \pm 0,76$ \\
Air & $4,95 \pm 0,48$ & $39,26 \pm 0,69$ \\
Abu & $6,33 \pm 0,18$ & $9,67 \pm 0,07$ \\
Serat & $0,22 \pm 0,26$ & $0,67 \pm 0,42$ \\
Vitamin C & $7,04 \pm 0$ & $14,08 \pm 0,73$ \\
Antioksidan & $42,78 \pm 0,20$ & $67,34 \pm 0,09$ \\
\hline
\end{tabular}

Keterangan : P0K2 $=$ Sari buah pedada : karagenan $(0$ $\mathrm{ml}: 20 \mathrm{gr}) ; \mathrm{P} 2 \mathrm{~K} 2=$ Sari buah pedada:karagenan $(100 \mathrm{ml}$ : $20 \mathrm{gr})$.

\section{Kadar Karbohidrat}

Karbohidrat merupakan senyawa organik yang mengandung unsur karbon, hidrogen dan oksigen dan pada umumnya unsur hidrogen dan oksigen dalam komposisi menghasilkan $\mathrm{H}_{2} \mathrm{O}$ (Proverawati, 2010). Karbohidrat merupakan zat gizi makro. Karbohidrat ada yang dapat dicerna oleh tubuh sehingga menghasilkan glukosa dan energi, dan adapula karbohidrat yang tidak dapat dicerna yang berguna sebagai serat makanan. Karbohidrat dalam makanan dikelompokkan menjadi monosakarida, disakarida dan polisakarida. (Anonim, 2010).

Hasil penelitian memperlihatkan kadar karbohidrat permen jelly buah pedada dengan penambahan karagenan pada perlakuan P0K2 lebih tinggi dibandingkan perlakuan $\mathrm{P} 2 \mathrm{~K} 2$. Berdasarkan Tabel 2 pada perlakuan P2K2 (100 ml sari buah pedada dan $20 \mathrm{gr}$ karagenan) kadar karbohidrat yaitu 69,83\% lebih tinggi dibandingkan perlakuan P0K2 (0 ml sari buah pedada dan 20 gr karagenan) yaitu 49,62\%. Kadar karbohidrat pada hasil penelitian ini menunjukkan penambahan sari buah pedada mempengaruhi kadar karbohidrat pada permen jelly buah pedada. Adanya perbedaan kadar karbohidrat pada permen jelly P0K2 dan P2K2 disebabkan adanya penambahan sari buah pedada dan karagenan serta penggunaan gula sukrosa dan fruktosa pada pengolahan. Hal ini sesuai dengan penelitian Ramadani et al (2019) dimana kadar karbohidrat pada buah pedada segar yaitu 26,89 \% sedangkan karagenan memiliki kandungan serat, kaya akan komponen seperti karbohidrat, protein, lemak, enzim, asam nukleat, asam amino, mineral, dan vitamin $\mathrm{A}, \mathrm{B}, \mathrm{C}, \mathrm{D}, \mathrm{E}$, dan $\mathrm{K}$ (Karyani, 2013). Sehingga kandungan karbohidrat buah pedada dan karagenan mempengaruhi kadar karbohidrat pada permen jelly. Menurut pendapat Sunarwati (2011) bahwa bahan yang mengandung karbohidrat bila ditambahkan dengan suatu produk maka kandungan karbohidratnya akan meningkat selama proses pemasakan.

\section{Kadar Protein}

Protein merupakan makromolekul linear hasil kondensasi berbagai jenis A-Lasam yang mempunyai variasi berat molekul, muatan dan sifat polaritas dan berikatan melalui ikatan peptida (Estiasih,2016).

Hasil penelitian memperlihatkan kadar protein permen jelly buah pedada dengan penambahan karagenan pada perlakuan P0K2 
dan P2K2 memilki nilai yang berbeda. Berdasarkan Tabel 2 pada perlakuan P2K2 (100 ml sari buah pedada dan $20 \mathrm{gr}$ karagenan) kadar protein yaitu 5,66 \% lebih tinggi dibandingkan perlakuan P0K2 $(0 \mathrm{ml}$ sari buah pedada dan 20 gr karagenan) yaitu $2,94 \%$. Hal ini menunjukkan penambahan sari buah pedada memengaruhi kadar protein permen jelly buah pedada.

Adanya perbedaan kadar protein pada permen jelly disebabkan adanya penambahan sari buah pedada dan karagenan. Hal ini sesuai dengan penelitian Ramadani et al (2019) dimana kadar protein pada buah pedada segar yaitu 3,45 \% sedangkan karagenan memiliki kandungan serat, kaya akan komponen seperti karbohidrat, protein, lemak, enzim, asam nukleat, asam amino, mineral, dan vitamin A, B, C, D, E, dan $\mathrm{K}$ (Karyani, 2013). Sehingga kandungan protein sari buah pedada dan karagenan mempengaruhi kadar protein pada permen jelly.

\section{Kadar Lemak}

Lemak merupakan sumber zat tenaga yang kdua setelh karbohidrat, molekul lemak terdiri dari unsur karbon, hidrogen dan oksigen. Lemak memeberikan rasa halus dan gurih pada makanan dan dapat memberikan rasa kenyang lebih lama (Muctadi, 2013).

Hasil penelitian memperlihatkan kadar lemak permen jelly buah pedada dengan penambahan karagenan pada perlakuan P0K2 dan P2K2 memilki nilai yang berbeda. Berdasarkan Tabel 2 pada perlakuan P2K2 (100 ml sari buah pedada dan 20 gr karagenan) kadar lemak yaitu 9,89\% lebih tinggi dibandingkan perlakuan P0K2 $(0 \mathrm{ml}$ sari buah pedada dan 20 gr karagenan) yaitu $1,84 \%$. Hal ini menunjukkan penambahan sari buah pedada mempengaruhi kadar lemak pada permen jelly buah pedada.

Adanya perbedaan kadar lemak pada permen jelly disebabkan adanya penambahan sari buah pedada, karagenan gula sukrosa dan fruktosa pada proses pengolahan. Hal ini sesuai dengan penelitian Ramadani et al (2019) dimana kadar protein pada buah pedada segar yaitu $0,66 \%$ sedangkan karagenan memiliki kandungan serat, kaya akan komponen seperti karbohidrat, protein, lemak, enzim, asam nukleat, asam amino, mineral, dan vitamin A, B, C, D, E, dan K(Karyani, 2013).

\section{Kadar Air}

Kadar air menunjukkan air yang terdapat dalam bahan atau produk pangan apapun keadaanya, baik terikat dalam bentuk hidratasi, permukaan, maupun air bebas, kadar air pada suatu produk pangan akan mempengaruhi penampakan, tekstur, cita rasa, dan keawetannya (Estiasih, 2016).

Berdasarkan Tabel 2 pada perlakuan P2K2 (100 ml sari buah pedada dan $20 \mathrm{gr}$ karagenan) kadar air yaitu 39,26\% lebih tinggi dibandingkan perlakuan P0K2 $(0 \mathrm{ml}$ sari buah pedada dan 20 gr karagenan) yaitu $4,95 \%$. Hal ini disebabkan adanya penambahan sari buah pedada dan karagenan mempengaruhi kadar air pada permen jelly buah pedada. Buah pedada memiliki kadar air sebesar 67,8\% (Ramadani et al,. 2019) dan karagenan memiliki kadar air sebesar $11,46 \%$ (Murdinah et al.,2007). Kadar air permen jelly semakin meningkat seiring bertambahnya jumlah buah pedada. Hal ini disebabkan oleh perbandingan penambahan karaginan dan sari buah pedada dalam pembuatan permen jelly (Murdinah et al.,2007). Harijono (2001) menyatakan bahwa kemampuan karagenan dalam mengikat air sesuai dengan literatur yang menyatakan bahwa karagenan sebagai hidrokoloid memiliki kemampuan untuk mengikat air dalam jumlah besar.

Kadar air permen jelly pada penelitian ini dengan perlakuan K2P2 dan K0P2 lebih tinggi dari standar mutu permen jelly (SNI 
3547-2-2008) yaitu maksimal 3,5\% (BSN, 2008). Menurut Subaryno (2006), kadar air permen jelly ditentukan oleh lamanya pemasakan dan pengeringan produk permen. Selanjutnya Buckle et al. (2007) menyatakan bahwa untuk mendapatkan kadar air yang rendah harus mengalami pemasakan yang lebih lama tetapi menghasilkan permen jelly yang berwarna kecoklatan akibat karamelisasi, sedangkan kadar air yang terlalu tinggi akan mengurangi keawetan produk karena mikroba akan lebih mudah berkembang biak.

\section{Kadar Abu}

Kadar abu merupakan zat organik sisa hasil pembakaran suatu bahan organik. Penentuan kadar abu berhubungan erat dengan kandungan mineral yang terdapat dalam suatu bahan yang dihasilkan. Pengukuran kadar abu bertujuan untuk mengetahui besarnya kandungan mineral yang terdapat dalam makanan/pangan (Persagi, 2009).

Berdasarkan Tabel 2 pada perlakuan P2K2 (100 ml sari buah pedada dan $20 \mathrm{gr}$ karagenan) kadar abu yaitu 9,67\% lebih tinggi dibandingkan perlakuan P0K2 (0 ml sari buah pedada dan 20 gr karagenan) yaitu $6,33 \%$. Kadar abu permen jelly pada penelitian ini dengan perlakuan K2P2 dan K0P2 lebih tinggi dari standar mutu permen jelly (SNI 3547-2-2008) yaitu maksimal 2,0 $\%$ (BSN, 2008). Hal ini disebabkan oleh banyaknya mineral yang terdapat pada buah pedada yang ditambahkan dalam pembuatan permen jelly. Kandungan abu dan komposisinya tergantung pada macam bahan yang dianalisis dan cara pengabuannya (Budiyanto 2002).

Kadar abu akan semakin tinggi seiring dengan meningkatnya penambahan sari buah pedada dan karagenan dalam pembuatan permen jelly. Hal ini disebabkan semakin banyak penambahan sari buah dan karagenan dalam permen jelly maka semakin meningkat kadar abu dalam permen jelly. Menurut Nurwati (2011), kadar abu buah pedada sebesar 45\% dan (Murdinah 2007), menjelaskan kadar abu karagenan sebesar 16,07\%.Penelitian ini sejalan dengan Hunaefi (2002) menyatakan tinggi atau rendah kadar abu permen jelly disebabkan rendahnya kandungan senyawa anorganik dalam bahan penyusunnya. Karagenan memiliki kandungan unsur-unsur mineral makro yaitu kalsium sebesar 186,00 ppm dan fosfor sebesar 2,76 ppm serta unsur mineral mikro yaitu besi sebesar 2,12 ppm (Winarno, 2008). Jumlah karagenan yang semakin meningkat mampu mengikat lebih banyak mineral dari bahan, air dan padatan terlarut, sehingga meningkatkan kadar abu (Estiasih dan Ahmadi, 2009).

\section{Kadar Serat}

Serat adalah jenis karbohidrat yang tidak terlarut. Serat dalam saluran pencernaan manusia tidak dapat dicerna karena manusia tidak memilki enzim yang mencerna serat, tetapi dalam usus besar manusia terdapat beberapa bakteri yang dapat mencerna serat menjadi komponen serat sehingga produk yang dilepas dapat diserap kedalam tubuh dan dapat digunakan sebagai sumber energi (Anonim, 2010).

Berdasarkan Tabel 2 pada perlakuan P2K2 (100 ml sari buah pedada dan $20 \mathrm{gr}$ karagenan) kadar serat yaitu $0,67 \%$ lebih tinggi dibandingkan perlakuan P0K2 $(0 \mathrm{ml}$ sari buah pedada dan 20 gr karagenan) yaitu $0,22 \%$. Hal ini disebabkan adanya penambahan sari buah pedada mempengaruhi kadar serat pada permen jelly buah pedada. Dalam 100 gr buah pedada mengandung $4 \mathrm{~g}$ serat (Ghalib et al., 2011). Kadar serat akan semakin tinggi seiring dengan meningkatnya penambahan sari buah pedada dan karagenan dalam pembuatan permen jelly. Hal ini disebabkan semakin banyak penambahan sari buah dan karagenan dalam permen jelly maka 
semakin meningkat kadar abu dalam permen jelly ( Nurwati, 2011). Sedangkan karagenan memiliki kandungan serat, kaya akan komponen seperti karbohidrat, protein, lemak, enzim, asam nukleat, asam amino, mineral, dan vitamin $\mathrm{A}, \mathrm{B}, \mathrm{C}, \mathrm{D}, \mathrm{E}$, dan K(Karyani, 2013).

\section{Kadar Vitamin C}

Vitamin $\mathrm{C}$ atau asam askorbat adalah Kristal putih yang mudah larut dalam air (Almatsier, 2009). Berdasarkan Tabel 2 pada perlakuan P2K2 (100 ml sari buah pedada dan 20 gr karagenan) kadar vitamin $C$ yaitu $14,08 \mathrm{mg}$ lebih tinggi dibandingkan perlakuan P0K2 $(0 \mathrm{ml}$ sari buah pedada dan 20 gr karagenan) yaitu 7,04 mg. Hal ini diduga berkaitan dengan adanya penambahan sari buah pedada dan karagenan mempengaruhi kadar vitamin $\mathrm{C}$ pada permen jelly buah pedada.

Pada 100 gram buah pedada segar memilki $66 \mathrm{mg}$ vitamin C (Ramadani et al., 2019). Karagenan merupakan bahan pembentuk gel terbuat dari rumput laut yang juga memiliki kandungan vitamin C. Hal ini sesuai dengan pendapat Suparti dan Sahri (2009) bahwa kadar vitamin C pada rumput laut merah mencapai $100-800 \mathrm{mg} / \mathrm{kg}$ per berat ke ring. Konsentrasi karagenan yang tinggi mampu membentuk disperse koloid (struktur double helix) yang lebih banyak dan kuat sehingga akan menghambat oksidasi vitamin $\mathrm{C}$ dan karagenan lebih kuat melindungi vitamin $\mathrm{C}$ dengan matriks yang kuat. Adanya penambahan sari buah pedada dan karagenan pada sampel P2K2 mempengaruhi nilai vitamin $\mathrm{C}$ pada permen jelly dibandingkan sampel P0K2 tanpa sari buah pedada. Rendahnya kadar vitamin C pada permen jelly berkaitan dengan proses pengolahan yang menyebabkan menurunnya kadar vitamin $\mathrm{C}$, elama proses pemasakan pembuatan permen jelly, vitamin $\mathrm{C}$ mengalami penurunan. Kerusakan vitamin $\mathrm{C}$ disebabkan oleh oksidasi vitamin $\mathrm{C}$ menjadi asam dehidroaskorbat, oksidasi selanjutnya akan menghasilkan asam diketogulonat yang tidak mempunyai aktivitas sebagai vitamin $\mathrm{C}$. Selain itu vitamin $\mathrm{C}$ berkurang akibat proses pengupasan kulit buah pedada. Hal ini sesuai dengan pendapat Ummu et al (2010) yang menyatakan bahwa menurunnya kadar vitamin $\mathrm{C}$ disebabkan karena kerusakan sel buah pada saat pengupasan dan terjadi reaksi kimia, ketika sel pada buah terluka maka enzim asam askorbat oksidase akan keluar dan mengakibatkan perubahan asam askorbat menjadi DHA (dehydroascpbicacid).

\section{Aktivitas Antioksidan}

Antioksidan adalah senyawa yang mempunyai struktur molekul yang dapat memberikan elektronnya kepada molekul radikal bebas dan dapat memutus reaksi berantai dari radikal bebas (Kumalaningsih, 2006).

Berdasarkan Tabel 2 pada perlakuan P2K2 (100 ml sari buah pedada dan $20 \mathrm{gr}$ karagenan) persen inhibisi aktivitas antioksidan yaitu $67,34 \%$ lebih tinggi dibandingkan perlakuan P0K2 $(0 \mathrm{ml}$ sari buah pedada dan 20 gr karagenan) yaitu $42,78 \%$. Hasil uji antioksidan pada sampel permen jelly buah pedada memiliki nilai lebih rendah dari nilai inhibisi $\alpha$-tokoferol yaitu $96,25 \%$.

Nilai inhibisi pada sampel yang berbeda, berkaitan dengan adanya penambahan sari buah pedada yang mempengaruhi inhibisi aktivitas antioksidan, penelitian ini sejalan dengan Avenido dan Serrano (2012) yaitu buah pedada merupakan salah satu tumbuhan yang berpotensi sebagai antioksidan, tumbuhan ini mengandung senyawa alkaloid, flavonoid, glikosida,saponin dan fenol.

Berdasarkan hasil penelitian dapat diketahui bahwa sampel P2K2 memilki aktifitas antioksidan yang sedang sedangkan 
sampel P0K2 memilki aktifitas atioksidan yang lemah. Dimana secara spesifik dikatakan suatu senyawa mempunyai aktifitas antioksidan yang sangat kuat jika mampu menghambat perkembangan radikal bebas lebih dari $80 \%$. Dikatakan sedang jika mampu menghambat sebesar 50-80 \% dan dikatakan lemah jika mempunyai kemampuan penghambatan kurang dari $50 \%$ (Sandrasari, 2008).

Tinggi atau rendahnya aktivitas antioksidan sampel dengan metoda penangkapan radikal DPPH ini diketahui dari persentase inhibisinya. Semakin besar nilai persentase inhibisi sampel maka semakin tinggi aktivitas antioksidannya. Proses inhibisi diperkirakan terjadi ketika radikal DPPH bereaksi dengan senyawa antioksidan melalui pengambilan ion hidrogen. Nilai inhibisi dari sampel permen jelly mempunyai persen inhibisi dibawah $\alpha$-tokoferol. Hal ini kemungkinan adanya perbedaan kadar atau jumlah metabolit sekunder yang aktif antioksidan (Latief, 2013).

\section{SIMPULAN}

Karakteristik kimia pada permen jelly buah pedada dengan perlakuan terbaik $\mathrm{P} 2 \mathrm{~K} 2$ $(100 \mathrm{ml}$ sari buah pedada dan 20 gr karagenan) mengandung kadar karbohidrat $69,83 \%$, protein $5,66 \%$, lemak $9,89 \%$, kadar air $39,26 \%$ (belum memenuhi standar mutu permen jelly SNI 3547-2-2008), kadar abu 9,67\% belum memenuhi standar mutu permen jelly SNI 3547-2-2008), serat 0,67\%, vitamin C 14,08\% dan aktivitas antioksidan $67,34 \%$ daya hambat radikal bebas dalam kategori sedang. Pada penelitian selanjutnya konsentrasi sari buah pedada perlu diturunkan dan karagenan terbaik digunakan 20 gram pada pembuatan permen jelly. Serta perlu dilakukan penelitian lebih lanjut permen jelly buah pedada dengan penambahan karagenan untuk memenuhi syarat mutu SNI 3547-2-2008 pada kadar air dan kadar abu permen jelly, uji mikroba dan penyimpanan pada permen jelly buah pedada. Sebaiknya masyarakat dapat memanfaatkan buah pedada menjadi olahan yang bernilai ekonomis dan menjadi sumber pangan yang bergizi.

\section{DAFTAR PUSTAKA}

[AOAC] Association of Official Analytical Chemist.1995. Official Method of Analysis of the Association of Official Analytical Chemist. Benyamin Franklin Station : Washington D.C.

— 1984. Official Method of Analysis of the Association of Official Analytical Chemist. Benyamin Franklin Station : Washington D.C.

[BSN] Badan Standardisasi Nasional. 1992. SNI 01-2891-1992. Cara Uji Makanan dan Minuman. BadanStandardisasi Nasional: Jakarta.

—. 2008. SNI 3547.2.2008Kembang GulaBagian 2: Lunak. BadanStandardisasi Nasional: Jakarta.

Afriyanto, Akhyar, A., Rahmayuni. 2016. Pengaruh Penambahan Karagenan Terhadap Mutu Permen Jelly Dari Buah Pedada. Jurnal Jom Faperta 3(2): $1-9$.

Almatsier, Sunita. 2009. Prinsip Dasar Ilmu Gizi. Gramedia: Jakarta.

Anonim. 2010. Gizi dan Kesehatan Masyarakat .Departemen Gizi dan Kesehatan Masyarakat Fakultas Kesehatan Masyarakat Universitas Indonesia. Rajagrafindo Persada: Jakarta.

Atmaka, W., Nurhartadi, E., Karim, M. 2013. PengaruhPenggunaan Campuran Karagenan dan KonjakTerhadap Karakterisik Permen Jelly Temulawak(Curcuma xanthorrhiza Roxb.). Jurnal TeknosainsPangan, 2 (2). ISSN: 2302-0733.

Avenido, P dan Serrano, A.E. 2012. Effects Of The Apple Mangrove (SonneratiaCaseolaris) On Growth, Nutrient Utilization And Digestive 
Enzyme Activities OfTheblack Tiger Shrimp Penaeus Monodon Postlarvae. European Journal ofExperimental Biology.

Buckle, K.A., Edwards, R.A., Fleet, G.H, Wooton, M. 2007. Food Science. DGHE IDP International Development Program of Australian Universities and Colleges.

Budiyanto A. K. 2002. Dasar-Dasar Ilmu Gizi. Universitas Muhammadiyah Malang :Malang.

Estiasih, T. dan K. Ahmadi. 2009. Teknologi Pengolahan Pangan. PT Bumi Aksara. Jakarta.

Estiasih. 2016. Kimia dan Fisik Pangan. Cetakan Pertama Perpustakaan Nasional, Jakarta.

Febrianti, F. 2010. Kandungan TotalFenol, Komponen Bioaktif,Dan Aktivitas AntioksidanBuah Pedada (Sonerattiacaseolaris). Skripsi FakultasPerikanan dan Ilmu KelautanInstitut Pertanian: Bogor.

Ghalib, R.M., Hashim, R., Sulaiman, O., Awaluddin, M.F.B., Mehdi, S.H., Kawamura, F. 2011. Fingerprint Chematoxonomic GC_TOFMS Profile of Wood and Bark of Mangrove Tree Sonneratia caseolaris(L.)Engl. Journal of Saudi Chemical Society 15(3):229-237.

Harijono., Kusnadi,J. dan S. A. Mustikasari. 2001. Pengaruh Kadar karagenan dan total padatan terlarut sari buah apel muda terhadap aspek kualitas permen Jelly . Jurnal Teknologi Pertanian, 2(2): $110-116$.

Hunaefi, D. 2002. Aplikasi gelatin dari ikat cucut dan ikan pari pada pembuatan permen jelly. Skripsi. Fakultas Teknologi Pertanian, Institut Pertanian Bogor. Bogor.

Isnanda, D., Novita, M., Rohayah, S. 2016. Pengaruh Konsentrasi pectin dan Karagenan Terhadap Permen Jelly Nanas (Ananas comosus L. Merr). Jurnal Ilmiah Mahasiswa Pertanian Unsyiah 1(10): 912-923.
Karyani, Said. 2013. Analisis Kandungan Food Grade Pada Karagenan Dari Ekstraksi Rumput Laut Hasil Budidaya Nelayan Seram Bagian Barat. Jurnal Bimafika 4(1):499-506.

Kumalaningsih, Sri. 2006. Antioksidan Penangkal Radikal Bebas. Trubus Agrisarana: Surabaya.

Kusmana, C., Dodi, S., Nyoto, S., Rinekso, S. 2008. Ekologi Tumbuhan Pedada (Sonneratia caseolaris (L) Engler 1987) pada kawasan Muara Angke Propinsi Daerah Khusus Ibukota Jakarta. Jurnal KKMN 54(8):1-4.

Langendorff, V., Cuvelier, G., michon, C., Launay, B., Parkek, A., De kruif, C.G. 2000. Effects of carrageenan type on the behavior of carrageenan or milk mixtures. FOOD Hydrocolloids. 14(1): 273-280.

Latief, M., Tafzi, F., Saputra, A. 2013. Aktivitas Antioksidan Ekstrak Metanol Beberapa Bagian Tanaman Kayu Manis (Cinnamomum Burmani) Asal Kabupaten Kerinci Provinsi Jambi. Prosiding Semirata FMIPA Universitas Lampung: Lampung.

Manalu. 2011. KadarBeberapa Vitamin Pada BuahPedada (Sonneratiacaseolaris) Dan HasilOlahannya. SkripsiDepartemen Teknologi HasilPerairan. Fakultas Perairan danIlmu Kelautan InstitutPertanian Bogor:Bogor.

Muchlisah. 2012. Studi Proses Produksi Karaginan Murni (Refine carrageenan) Dari Rumput Laut Eucheuma cottonii Secara Ohmic : Pengaruh Lama Ekstraksi Dan Suhu Alkalisasi. Skripsi. Program Studi Keteknikan Pertanian Jurusan Teknologi Pertanian Fakultas Pertanian Universitas Hasanuddin Makassar: Makasar.

Muchtadi, 2013. Prinsip Proses dan Teknologi Pangan. Alfabeta: Bogor.

Murdinah. 2010. Pemanfaatan rumput laut dan fikokoloid untuk produk pangan dalam rangka peningkatan nilai tambah dan 
diversifikasi pangan. Balai Besar Riset Pengolahan Produk dan Bioteknologi Kelautan dan Perikanan. Jakarta.

Nursyamsiati. 2013. Studi Pembuatan Permen Jelly Ubi Jalar Ungu (Ipomea batatas L.) dan Rumput Laut (Eucheuma cottonii). Skripsi. Program Studi Teknologi Hasil Pertanian Fakultas Pertanian Universitas Riau: Pekanbaru.

Nurwati. 2011. Formulasi hard candy dengan penambahan ekstrak buah pedada (Sonneratia caseolaris) sebagai flavor. Skripsi. Departemen teknologi hasil perairan fakultas perikanan dan ilmu kelautan institut pertanian Bogor. Bogor.

Persagi (Persatuan Ahli Gizi Indonesia). 2009. Tabel Komposisi Pangan Indonesia (TKPI). Elex Media Komputindo: Jakarta.

Proverawati. 2010. Ilmu Gizi. Penerbit Nuha Medika: Yogyakarta.

Ramadani, D.W., Meilina, M., Arsita, Y., Dari, D.W., Safitri, N. 2019. Pengaruh penambahan gula terhadap karakteristik kimia sirup pedada (Sonneratia Caseolaris). Prosiding S1 Ilmu Gizi STIKes Baiturrahim: Jambi.

Sari, Y. 2013. Al Akhmar, Ciptakan Sirup dari Buah Pedada .http://www. Jambiup date.co. (Diakses pada tanggal 2 Januari 2019).

Septiadi, A. 2010. MangrovepunMenghasilkan PanganBergizi. http://www.Kesehatan.kompasiana.com . (Diakses pada tanggal 2 Januari 2019)

Subaryono dan B. S. B. Utomo. 2006. Penggunaan campuran karagenan dan konjak dalam pembuatan permen jelly. Jurnal Pascapanen dan Bioteknologi Kelautan dan Perikanan, Vol 1 (1) : 1926.

Suparti dan A. Sahri. 2009. Mengenal potensi rumput laut: kajian pemanfaatan sember daya rumput laut dari aspek industri dan kesehatan. Sultan Agung 24 (1): 85-115.

Susanto, N., Kusmana, C., Sudarma, D., Sukmadi, R. 2008. Ekologi Tumbuhan
Pedada (Sonneratia caseolaris) (L) Engler 1987 Pada Kawasan Muara Angke Provinsi Daerah Khusus Ibu Kota Jakarta. Jurnal KKMN.

Ummu, M., S.H. Susetyorini dan S. Aminah. 2010. Kadar vitamin $C$, mutu fisik, $p H$ dan mutu organoleptik sirip rosella (Hibiscus Sabdariffa, L) berdasarkan cara ekstraksi. Jurnal Pangan dan Gizi 1 (1): 43-51.

Winarno, F.G. 2008. Kimia Pangan dan Gizi. Gramedia Pustaka: Jakarta. 